\title{
Historical Narrative and Tradition as Instruments of Creating the Image of the State on the International Arena: The Case of Kazakhstan
}

\section{Narracja historyczna i tradycja jako narzędzia kreowania wizerunku państwa na arenie międzynarodowej na przykładzie Kazachstanu}

\section{- Abstrakt •}

Artykuł ma na celu wyjaśnienie związków, jakie zachodzą pomiędzy oficjalną narracją historyczną (polityką pamięci) a kreowaniem wizerunku państwa na arenie międzynarodowej (nation branding). Analiza została oparta w głównej mierze na kazachskiej kinematografii i programach stacji Kazakh TV.

Autor twierdzi, że oficjalna narracja historyczna Kazachstanu może przyczyniać się do zmiany wizerunku tego państwa na arenie międzynarodowej. Polityka pamięci jest nakierowana na eksponowanie pewnych okresów historycznych, a pomijanie innych. W przypadku Kazachstanu władze promują historię najnowszą, modernizację i sukcesy państwa po 1991 roku. Wiele mówi się także o historii przedsowieckiej, podkreślając historyczną ciągłość kazachskiego narodu (a nawet jego państwowości) od XV wieku. Polityka pamięci ma także na celu retradycjonalizację, silnie eksponuje się tradycyjny styl życia koczowników. Z kolei okres rosyjskiego i sowieckiego panowania jest z regu-

\section{- Abstract •}

The article aims to explain the relationships between the official historical narrative (politics of memory) and the image of the state on the international area (nation branding). The analysis was based mainly on the Kazakh cinematography and the Kazakh TV station programs.

I argue that the official historical narrative may contribute to the change of Kazakhstan perception on the international area. Politics of memory aims at highlighting the selected historical periods and concealing others. Kazakhstan elites are trying to emphasize the recent history, modernization and economic successes of the state after 1991. The pre-Soviet history is also strongly accentuated, and the historical continuity of the Kazakh nation (or even its statehood) from the end of the 15th century is highlighted. The politics of memory also aims at retraditionalization, i.e., the traditional lifestyle of nomads is widely publicized. On the other hand, the period of Russian and Soviet rule, painful events in the history of the twentieth century, are omitted 
ły pomijany czy też ukrywany. Taki sposób kreowania oficjalnej narracji może przyczyniać się do zmiany wizerunku z państwa postsowieckiego w państwo nowoczesne, zmodernizowane, ale jednocześnie „koczownicze”, o bogatej tradycji.

Słowa kluczowe: polityka pamięci; Azja Centralna; Kazachstan; kreowanie wizerunku państwa (nation branding) or even concealed. Such a manner of conducting politics of memory may change the image of Kazakhstan, from the post-Soviet state to a modern one, modernized but at the same time nomadic, with a rich tradition.

Keywords: politics of memory; Central Asia; Kazakhstan; nation branding

The main aim of the article is to explain the relationship between the historical narrative constructed by the state and the state's image on the international arena. May the official historical narrative be an element of the state promotion on the international arena? Which of the instruments of the politics of memory play the most significant role in the process of creating the positive image of the state abroad?

In order to answer these questions it is necessary to clarify the concepts that will be used below. In the scientific literature, a variety of terms are used to describe the relationship between history and politics. In the further part of the article, the concept of the state politics of memory will be used. Perhaps it most fully reflects the phenomenon important for the analysis. The main (final) goal of the elites is not to change the historical narrative, but rather to alter the manner of remembering the selected historical events. With this in mind, official historical narrative should be treated only as an instrument to change memory. The definition of the state's politics of memory is provided by sociologist Lech Nijakowski: "all intentional actions of politicians and officials with formal legitimacy aimed at perpetuating, removing or redefining specific contents of the social memory" (Nijakowski, 2008, p. 44).

In the studies on the politics of memory (or politics of history), first of all legitimizing function of history is emphasized, that is, the possibility of using the interpretation of the past as an instrument to gain or retain power (Ponczek, 2015). The elites interpret history in such a way as to mobilize selected social groups. When it is conducted in such a manner, it may often lead to falsification or mythologization of history.

The vast majority of authors emphasize the internal functions of the memory politics. In the context of this article, there is another interesting issue: can politics of memory also play a role in international relations, that is, may it influence relations between the states? In the literature regarding politics of memory, authors tend to focus on its possible negative implications on the international arena. It 
is argued that memory politics can be a part of foreign policy, it may be: "a highly sensitive action, polarizing international relations" or just "a way to conduct a diplomatic game" (Ponczek, 2015, p. 33). It is noted that nationalistic narrative can easily lead to conflicts with neighbours, for instance, by creating national prejudices. In this context, looking at the Central Asia region, one can recall Tajik and Uzbek historians' disputes about the settlement or the nomadicity of their ancestors (Włodek, 2016).

The politics of memory may also be aimed at legitimization of the territory, and such narratives may be conflictual. One example is the concept of the Great Tajikistan promoted by Tajik elites, which raises disagreements with neighbouring Uzbekistan (Abashin, 2012, pp. 163-164). The politics of memory (or mythologized history) may be aimed at confirming the nationality of an outstanding historical figure. In Central Asia disputes arise, inter alia, about the nationality of Al-Farabi. Kazakhstan, Uzbekistan and Tajikistan recognize the outstanding teacher of Islam as solely their ancestor (Galiev, 2015).

It should be noted that in the literature one can find the term "cross-border politics of history" (Hahn, 2008). However, the author of this concept, historian Hans Henning Hahn, writes about the need to create the code of memory practices in Europe, and his remarks can be used to a limited extent in the analysis.

In the literature on memory politics the role of historical narrative in promoting the state on the international arena is usually neglected. This aspect is emphasized rather by the authors dealing strictly with nation branding. They are accentuating the role that history and tradition can play in creating the image of the state abroad. However, before we deal with this issue in more detail, it is worth defining the very concept of nation branding.

Simon Anholt defines branding as: "the process of designing, planning and communicating the name and the identity, in order to build or manage the reputation" (Anholt, 2007, p. 4). It is significant that Anholt emphasizes close connection between the national identity and the creation of the image of the state on the international arena: "national identity and nation brand are virtually the same thing: nation brand is national identity made tangible, robust, communicable, and above all useful" (Anholt, 2007, p. 75). The elites of Central Asian states are being confronted with a double challenge, due to their young statehood, they are trying to promote their country abroad, however at the same time they are seeking (or creating) their own identity.

The image of a country abroad might be communicated through a number of different channels. Simon Anholt mentions six natural channels of such transmission: tourism promotion, export brands (related to the country of origin ef- 
fect), policy decisions of country government (when they affect foreign nations or they get reported in international media), investment policy, cultural exchange and activities, population of the country (especially well-known citizens; Anholt, 2007, p. 25).

How to combine the above-mentioned channels of transmitting the image of the state on the international arena with the official, historical narrative formulated by the elites? Undoubtedly, the memory politics can be implemented using various means and tools, due to that in the literature one cannot find an exhaustive catalogue of memory politics tools. As a rule, authors limit themselves only to indicate possible instruments for shaping collective memory, such as: official publications, use of mass media, education (history textbooks, curricula), manner of financing scientific research, naming of streets, squares and cities, organization of time (e.g., calendar national holidays), organization of space (e.g., putting up, but also removing monuments), state ceremonies, activities of specialized institutions (libraries, archives, memory institutes), legal and judicial tools (Kącka, 2015; Nijakowski, 2008).

Undoubtedly, not all of them will have the same influence on the internal recipient (citizen of the state) as they have on the external recipient. In Central Asia, the new historical narrative is probably most fully reflected in the presidents' works. However, it would be bizarre to assume that, for instance, an average European study the works of Nursultan Nazarbayev, Emomali Rahmon or Gurbanguly Berdimuhamedov. Bearing this in mind, their books are rather of minor importance for this analysis. The same can be said about the instruments such as: museum exhibitions, the organization of space (for instance through the creation of new monuments), or the manner of celebrating national holidays, as all of them require direct observation.

In the further part of the article, the particular attention will be given to those means that can reach the recipient who is not particularly interested in the Central Asian region. It seems that in the case of nation branding, attention should be focused on the cinematography, especially on the Kazakh films that are available in English language. The mass media will also be analysed, especially the promotional campaigns that were broadcast in the Western television stations. In case of regional media, it seems that there is only one television station of worldwide reach in Central Asia. Kazakh TV transmits its signal to several dozen countries and selected programs broadcast by this station will be cited below. 


\section{Nation Branding in Central Asia}

Central Asian countries encounter similar problems when it comes to creating an image on the international arena. The first of the common features is the fact that being young states, which have recently gained their independence (or regained according to their official narrative), they have to contend with two-pronged challenge: on the one hand, creating their image inside (among their own citizens), on the other, promoting their image outside (internationally). It seems that the nation building and the nation branding processes are inextricably linked in these countries. Robert Saunders aptly points out in this context: "while older countries enjoy well-established national images at home and abroad, the past century has seen the emergence of roughly one hundred new nations that face double challenge. They are charged first with crystallizing a coherent national image in the domestic realm, and second with transmitting a positive image of their country to the world community" (Saunders, 2008, p. 65).

One could say that the countries of the region are charged with one fundamental problem, which is the very low level of knowledge about the Central Asian republics in the international arena. The basic ability to indicate the location of the state on the world map is the first step to change the image of the state from the unknown and distant to a more friendly and worth visiting place. In the case of the Central Asian countries, as it is aptly pointed out by Maria Omelicheva: "even today, more than 20 years after the breakup of the Soviet Union, very few people, apart from real specialists, can tell the five Central Asian 'stans' apart" (Omelicheva, 2014, p. 170).

The problem of "stans" is an issue that needs to be discussed separately. For people who are not familiar with the regional specificity, all countries of Central Asia, because of the suffix "stan", are grouped with Afghanistan and Pakistan, often associated with political instability and the activities of terrorist groups. In 2014, Nursultan Nazarbayev proposed quite a radical variant of the "escape" from this issue, when he started the discussion of changing the state's name to Kazak Eli (in a literal translation - the state of Kazakhs). However, the proposal did not have sufficient social support, hence the idea was not implemented.

A little knowledge of the region is often complemented by a very negative and stereotypical image presented in the Western movies. The best-known example of this phenomenon is the film Borat!: Cultural Learnings of America for Make Benefit Glorious Nation of Kazakhstan, which presents Kazakhstan as a backward and intolerant country, a nation of anti-Semites and misogynists. Additionally, Kazakhstan appears in other well-known Hollywood films, and although not as much 
attention is paid to it as in the case of Borat, still the negative and stereotypical representation of this country is repeated. For instance: in the film Air Force One, Kazakhstan is presented as a country in the state of war, in one of the James Bond movies, The World is Not Enough, Kazakhstan is an extremely dangerous territory, in Rollerball - Kazakh people are very corrupted and brutal, finally in the horror The Cavern, it is the exotic and mysterious place (Frigerio, 2017, pp. 107-108).

This stereotypical manner of presenting Kazakhstan resulted in a definite reaction from the Kazakh authorities. Soon after Borat was distributed, the special department for international information, subordinated to the Minister of Foreign Affairs, was created. Its main task was to promote a positive image of Kazakhstan abroad (Marat, 2009, p. 1129).

The history of Russian and then Soviet rule has imposed another challenge on the countries, thus the elites still have to counter the post-Soviet label. The limited amount of knowledge about the Central Asia region means that the one or only the few connotations that external recipients have about the region is that these five republics were part of the USSR. Nowadays, the Central Asian elites are trying to alienate from this post-Soviet label by drawing the attention of the recipient on the other historical periods. In the case of Kazakhstan, firstly the authorities are referring to the most recent past, in particular to economic successes and modernization of the state after 1991.

\section{Modern History of Success}

In almost all Kazakh historical-sightseeing museums one can find the hall dedicated to the newest history, presenting events after 1991. Nursultan Nazarbayev usually occupies central place in such expositions. Photos from his meetings, obtained distinctions, as well as fragments of his statements or even copies of his books are displayed. Besides the Nursultan Nazarbayev activities, in these halls one can get familiar with events such as the first flight of Kazakh into space (Toktar Aubakirov), the history of creating the Eurasian Economic Union, the Kazakhs involvement in nuclear-free initiatives, the transfer of the capital from Almaty to Astana or about the organization of the OSCE summit and many others. The focus on the recent history is very visible not only in the museums, but also in the urban space, the Monument and Independence Park in Shymkent may serve as an example 1 .

\footnotetext{
${ }^{1}$ Based on the observation of the museum exhibitions, inter alia, in: the National Museum of
} 
Furthermore, the emphasis on the recent history is noticeable in the spots advertising Kazakhstan and broadcast in the global television stations. In the series of spots, called: Kazakhstan: Heart of Eurasia, modern architecture of Astana is presented in the first place. The Bajterek Tower, the Nazarbayev University and the Khan Shatyr shopping center are all displayed. However, it should be noted, that in these spots a lot of time is also devoted to ethnic traditions and culture, the modernity is combined here with the national tradition.

Appealing to the wider community or directing the recipient attention to a larger region might also be used as a way to escape from the soviet heritage. The "Heart of Eurasia" is the central slogan of the Kazakh promotional activities, which presents this state as a bridge connecting two continents. The slogan was first introduced by the president of Kazakhstan, Nursultan Nazarbayev, when his book In the Heart of Eurasia was published (Nazarbayev, 2010). The president argues that Astana can be called the centre of Eurasia because of its location the place where the civilizations of the West and the East intersected. The slogan from the president's book began to be used not only to promote the city, but also to promote the state itself to the international community (Insebayeva, 2017, pp. 60-61).

The concept of the "Heart of Eurasia" corresponds with the ideology of Eurasianism, promoted by the Kazakh government. In 1996 in Astana, the Lev Gumilev University (named after philosopher and theoretician of this ideology) was created, and in 2004, the Center for Eurasian Studies was established. The Kazakh version of Eurasianism is not synonymous neither with the thought of the first Eurasianists (Piotr Savickij, Lev Karsavin or Nikolaj Trubetzkoy) nor neo-Eurasianists (Aleksandr Dugin, Igor Panarin). Kazakh scholars have been dealing with the adaptation of Eurasianism to the needs of modern Kazakhstan for over ten years (Laruelle, 2008, pp. 10-11).

The idea of Eurasianism was consolidated through the organization of different events. In 2011, the Asian Winter Games were organized, with official mascot - Snow Leopard Irby. In this line one could interpret the organization of the OSCE Summit. It should also be added that Kazakhstan was hosting the EXPO exhibition and Winter Universiade in 2017 (Insebayeva, 2017, p. 61).

the Republic of Kazakhstan in Astana, the Central State Museum of Kazakhstan in Almaty, the East-Kazakhstan State Museum in Ust-Kamenogorsk, the South-Kazakhstan State Museum in Shymkent, conducted by the author in January-May 2018. 


\section{Mythologization and Heroization}

The concentration on the pre-Soviet history, the search for sources of the nationality and the statehood, as well as the construction of the new catalogue of national heroes are all evident features of the new historical narratives in Central Asia. These phenomena can be described as the "state-sponsored primordialism" (Kudaibergenova, 2014, p. 161). In this context Kazakhstan is not an exception, most state symbols are created in relation to the distant past.

This tendency is very visible in Kazakh cinematography. Perhaps, the most expressive reaction to the film Borat was the development of the Kazakh cinema. The authorities reacted to the pastiche of Sasha Baron Cohen not only by prohibiting its broadcast or the threat of referring the matter to court, but also by developing their own cinematography and attracting well-known global producers. Interestingly, in the context of this article, the most-recent films are historical films (Abikeyeva, 2006, p. 293). Usually, they concern distant past, they focus on national heroes. This does not mean that no films have been made about events from the $20^{\text {th }}$ century, but their number is much smaller. This type of productions, with one exception, i.e., the Mustafa Shokay feature (Narymbetov, 2008), are directed rather to the internal recipient, as films are predominantly distributed only in Kazakh language. Additionally, it is evident that the Kazakh elites avoid film productions that would refer to the painful events of the Soviet reign, such as political repression, famine in the 1930s, collectivization or the Zheltoksan (Jeltoqsan) uprising in December 1986 (Laruelle, 2015).

The most famous production of recent years was the film Nomad made in the French-Kazakh co-production. The government of Kazakhstan invested approximately 40 million dollars in this production and it was the most expensive film in the history of this country. An international cast was involved, and the big controversy was caused by the fact that the two main roles were played not by Kazakhs but by Mexican and American (of Mexican origin) actors (Jay Hernandez as Ablai Khan, Kuno Becker as a friend of Ablai, Erali). It is worth noting that Milos Forman was the executive producer, an outstanding director of such productions as One Flew Over the Cuckoo's Nest or Hair. Furthermore, the film was distributed in the United States by the well-known production company, Miramax (Bodrov $\&$ Passer, 2005).

The film presents the figure of Abilmansur (later known as Ablai Khan), who in the eighteenth century became famous for defending Turkestan from the Dzungars. The story is based on documented historical events only to a limited extent; the oral history and Nomad trilogy by Ilias Esenberlin were also used. The 
prophecy which states that the unification of the Kazakhs can be done only by a descendant of Genghis Khan (that descendant in the further part of the film turns out to be Ablai Khan) is the linchpin of the film. The expert of the Kazakh cinema, G. Abikeyeva, writes straightforwardly: "here we deal with the pure mythology" (2006, p. 284). However, it would not be fair to criticize the directors of Nomad on this basis, because such a way of producing historical films is already a common practice of many film production companies: "on the same principle most of the American films about Robin Hood, Alexander or Gladiator were made" (Abikeyeva, 2006, p. 284).

Another expensive production of the Kazakhfilm company was the film Myn Bala (Satayev, 2012), distributed in 2011 to commemorate the $20^{\text {th }}$ anniversary of Kazakh statehood. The film shows the legendary warrior Sartay Batyr, who repelled the Dzungar attacks in the eighteenth century. Approximately 7 million dollars have been invested in this production, as for Central Asian cinematography it was an extraordinary budget (Lillis, 2011).

In both of these films one can find many similarities ${ }^{2}$. The stories of Nomad and Myn Bala take place in the eighteenth century, and the main enemy are Dzungars. In both, the Kazakhs succeed in uniting in a situation of serious external threat. Finally, in the presented films we have a large dose of historical mythologization. The literature emphasizes that both Nomad and Myn Bala are focused on building a sense of national unity or stimulating patriotism among ethnic Kazakhs (Isaacs, 2015). The central place that Ablai Khan occupies in the film Nomad makes it possible to interpret this production as legitimizing the authoritarian system of power (Yessenova, 2011). Undoubtedly, however, the films also fulfil a promotional function, as they depict a nation that not only existed before the Soviet Union, but was able to unite, possessed substantial army and repulsed serious invasions of the enemies.

In Kazakh cinematography, one can find films which plot is strictly related to the issue of sources of nationality and statehood. Undoubtedly, the figure of Genghis Khan plays a considerable role in the Kazakh historiography. It is emphasized that the Kazakh Khans were descendants of Genghis Khan or even trying to prove the Kazakh origin of the creator of the Mongol empire. In this context, we should mention the film Mongol, Russian-German-Kazakh co-production (Bodrov, 2008). The film was planned as the first part of the trilogy and shows

${ }^{2}$ It should be added that the film Sardar was also created in a similar manner (Kalymbetov, 2003) and distributed in 2003; its plot takes place in the $18^{\text {th }}$ century and focuses on the war with Dzungars. However, the budget of the film was much smaller, therefore, it was not described above. 
only the youth of Genghis-Khan. Without going into the details, it depicts a wise and spiritual leader, a protective father and a caring husband, and almost completely ignores the uncomfortable threads of violent conquests and hard power. It is worth noting that the film was nominated for the Oscar in the Best Foreign Language Film category, and it was Kazakhstan who submitted the application (Stern, 2008).

One of the most significant moments in the Kazakh history was the establishment of the Kazakh Khanate. Its creation dates back to 1465, when Kerey and Janybek separated from the Abulchair trot, and it is treated as the beginning of the statehood. One may have some doubts about the actual "statehood" of this organism; it could be argued that it was rather a temporal association of tribes. Nevertheless, in 2015 a grand celebration of the $550^{\text {th }}$ anniversary of the Kazakh Khanate was organized. The celebration began with the opening of the monument of Kerey and Janybek in Taraz. During this ceremony, President Nursultan Nazarbayev emphasized: "The $550^{\text {th }}$ anniversary shows that the Kazakh nation and the Kazakh state have a long history. We show the world our great story" (Lillis, 2015). On the streets of the largest Kazakh cities, horse races, concerts and even wrestling tournaments dedicated to this anniversary took place. In the same year, the production of the television series titled Kazakh Khanate (Abdrashev, 2017) started. The series has already been filmed and presents the events of the fifteenth century, which led to the creation of this organism. There are plans to introduce Russian and English dubbing and to distribute the series outside the state borders (Lillis, 2016).

In addition to the cinematography, it is also worth briefly discussing the programs broadcast in the only Central Asian television station with worldwide reach. Kazakh TV, sponsored by the state, reaches almost 100 countries around the world. Programs are broadcast mostly in English, although Kazakh and Russian can also be heard. The television schedule is very interesting in the context of this article, as a significant part of the airtime is devoted to the historical or the ethnographic programs.

The series of programs such as Enigma of the Great Steppe and Reflections on History present the history of lands belonging to modern Kazakhstan. Others, such as Trails of Nomads or Central Asian Civilizations, display the history of Kazakhs from a broader perspective. Trails of Nomads is a program in which a group of scientists take a 70-day journey in the search of the traces of their ancestors. The authors reach, among others, Armenia, Georgia, Azerbaijan, Belarus, Ukraine, Lithuania, and Hungary. In each of these countries they find traces of the Kipchaks, whom they treat as direct ancestors of the Kazakhs. In Kazakh TV, 
the viewer can also see museum exhibitions from Kazakh cities. In the Museum's Secrets program, one can get familiar with the Museum of the First President in Astana, the Museum of Jambyl Jabaev in Taraz, the Ecological Museum in Karaganda and many others (Kazakh TV, 2018). It is impossible to analyse all of the above-mentioned programs, some of them have been broadcast for several years and consists of several dozen episodes. However, even their brief analysis reveals that the most of them focus on pre-Soviet history, often reaching even further than the end of the fifteenth century, that is, the establishment of the Kazakh Khanate.

All the above-mentioned films and television programs direct the viewer's attention to the rich history of the Kazakh nation. They present a picture of an uninterrupted and uniform state organism, diverting attention from the period of Russian rule. In all the above-mentioned productions, one more feature is also noticeable, in addition to the long history of Kazakhstan, the rich traditions of the nomadic nation are also emphasized.

\section{Retraditionalization}

As Sergey Abashin aptly points out, after 1991: "each Central Asian state strives to reconstruct the canonical image of its 'titular' nation - its traditional dress, cuisine, architecture, folklore, songs, dances, codes of conduct, moral values, rituals and so on" (Abashin, 2012, p. 154). This process is also very noticeable in Kazakhstan, undoubtedly the signs of retraditionalization or invented traditions, using the terminology of Eric Hobsbawm (2012), reach not only citizens, but also the external recipient.

New traditions are reproduced mainly through the reference to the nomadic lifestyle of Kazakh ancestors. Historical habits and rituals are recreated and the symbolism of the steppe is emphasized. This process is visible in the aforementioned film productions. As Stephen Norris points out, the films became a place: "where the past gets interpreted and ultimately an important place to examine for the emergence of nomadic nationhood" (Norris, 2012, p. 384). Both in Nomad and Myn Bala one can notice the glorification of nomadic lifestyle: yurts, dombras (national Kazakh stringed instrument), horse breeding or hunting with berkut (or the golden eagle) are highlighted.

The glorification of the nomadic lifestyle is noticeable in the Kazakh TV programs. Even the series titles: Modern Nomads and The School of Nomads reveal a lot. The viewer may become acquainted with the method of preparing 
shubat (a drink from camel milk) or kumis, get to know the manner of preparing saddle, and discover the importance of headgear for Kazakh culture (e.g., chapan or kalpak).

In the aforementioned spots, in many museums or in the urban space of Kazakh cities (even at the bus stops in Almaty) one can find the image of a bird hunter, usually with berkut. The tradition of hunting with birds has been experiencing a renaissance in the last dozen years. It is estimated that the number of falconers (berkutschi) exceeds 100 people. They meet annually at the national championships in Almaty. The Kazakh Ministry of Sport and Tourism considers this kind of hunting as a sport discipline (Bekentayeva, 2013).

Sport can be the subject of nation branding, which is evident on the example of the Kazakh cycling group Astana Pro Team. (szerzej zob. Koch 2013), and retraditionalization. The organization of the World Nomad Games is an excellent illustration of combining these two phenomena. This event is becoming one of the most important marketing ventures of neighbouring Kyrgyzstan. On September 2, 2018, the third edition of this event took place; representatives of 80 countries took part in it and competed in 37 competitions (World Nomad Games 2018, n.d.). Kazakhstan was one of the most active participants of the Nomadic Games, though it does not stop at passive participation, but also organizes its own sporting events for nomads. The National Berkutschi Championships have already been mentioned, and in 2017 (during the EXPO exhibition), the $1^{\text {st }}$ World Kokpar Championship took place('The First World "Kokpar" Championship', 2017). It is a traditional game for the Central Asian nations, in which two teams of horseback riders take part. The team's task is to win the sheep's body and throw it into the circles designated on the ground.

\section{Conclusion}

The article aimed to show the connection between the politics of memory and the process of building the image of the state on the international arena. The analysis was devoted mainly to cinematography and television, because it seems that these are the channels that can be most efficient in the case of nation branding.

On the example of Kazakhstan, it can be stated that the official narrative, by displaying selected historical events and emphasizing tradition (sometimes invented), is an important element of creating an image on the international arena. On the one hand, the external recipient observes the economically developed country, its high potential, and the modern capital - Astana. On the other hand, he sees the 
rich and uninterrupted history and tradition of the nomadic nation throughout the Soviet period. Thereby, Kazakhstan from a post-Soviet state becomes a modern state, modernized but at the same time nomadic, with a rich tradition.

As indicated above, the processes of nation building and nation branding in the case of Central Asian countries are inextricably linked. It is difficult to assess to what extent the official historical narrative is the result of the carefully thoughtout marketing strategy, and to what extent it is just the effect of the nation-building process. A complicated task is also to assess the impact of the projects chosen for the analysis on the perception of Kazakhstan abroad. One could look at the international perception rankings where Kazakhstan is classified rather low. According to the Digital Country Index, conducted by Bloom Consulting, Kazakhstan is ranked at the $96^{\text {th }}$ position (Bloom Consulting, 2017). Its position is not outstanding in the Country RepTrack ranking as well, in which he is placed on $47^{\text {th }}$ out of 55 classified countries (Reputation Institute, 2018).

\section{References:}

Abashin, S. (2012). Nation-Construction in Post-Soviet Central Asia. In: M. Bassin \& C. Kelly (eds.). Soviet and Post-Soviet Identities (pp. 150-168). Cambridge: Cambridge University Press. DOI: https://doi.org/10.1017/CBO9780511894732.012.

Abdrashev, R. (2017). The Kazakh Khanate: The Diamond Sword. Kazakhfilm Studios.

Abikeyeva, G. (2006). Natsiostroitel'stvo v Kazakhstane $i$ drugikh stranakh Tsentral'noy Azii, i kak etot protsess otrazhayet.sya v kinematografe. Almaty: CCAK.

Anholt, S. (2007). Competitive Identity: The New Brand Management for Nations, Cities and Regions. New York: Palgrave Macmillan.

Bekentayeva, M. (2013). Kazakhstan's Best Falconers Compete in National Championship. March 13. Retrieved from: https://astanatimes.com/2013/03/kazakhstans-best-falconers-compete-in-national-championship/.

Bloom Consulting (2017). The Digital Country Index'17. Retrieved from: https://www. digitalcountryindex.com/country-index-results.

Bodrov, S. (2008). Czyngis-Chan. Kazakhfilm Studios.

Bodrov, S., \& Passer, I. (2005). Nomad. Kazakhfilm Studios.

Frigerio, A. (2017). "Something-Stan": The Stereotypical Representation of Kazakhstan in International Movies vs. the Official Nation-Branding of the Kazakh Government. International Scientific Journal Theoretical \& Applied Science, 46(2), 106-115. DOI: https://doi.org/10.15863/TAS.2017.02.46.20.

Galiev, A. (2015). Natsional'nyye istorii Kazakhstana i ikh konfliktogennyy potentsial. In: A. Owczinnikow (ed.). Konfliktogennyy potentsial natsional'nykh istoriy (pp. 135-149). Kazan: Uniwersum.

Hahn, H.H. (2008). Pamięć zbiorowa - przedmiot polityki historycznej. In: B. Korze- 
niewski (ed.). Narodowe i europejskie aspekty polityki historycznej (pp. 29-42). Poznań: Instytut Zachodni.

Hobsbawm, E. (2012). Introduction: Inventing Traditions. In: E. Hobsbawm \& T. Ranger (eds.). The Invention of Tradition (pp. 1-14). Cambridge-New York: Cambridge University Press.

Insebayeva, S. (2017). Imagining the Nation: Identity, Nation Building, and Foreign Policy in Kazakhstan. In: M. Laruelle (ed.). Kazakhstan: Nation-Branding, Economic Trials, and Cultural Change. Washington, D.C.: The George Washington University.

Isaacs, R. (2015). Nomads, Warriors and Bureaucrats: Nation-Building and Film in Post-Soviet Kazakhstan. Nationalities Papers, 43(3), 399-416. DOI: https://doi.org/ 10.1080/00905992.2013.870986.

Kalymbetov, B. (2003). Sardar. Kazakhfilm Studios.

Kazakh TV (2018). Retrieved from: http://kazakh-tv.kz/ru/category/programms.

Kącka, K. (2015). Polityka historyczna: kreatorzy, narzędzia, mechanizmy działania - przykład Polski. In: K. Kącka, J. Piechowiak-Lamparska, \& A. Ratke-Majewska (eds.). Narracje pamięci: między polityką a historią (pp. 59-80). Toruń: Wydawnictwo Naukowe Uniwersytetu Mikołaja Kopernika.

Kudaibergenova, D.T. (2014). National Identity Formation in Post-Soviet Central Asia: The Soviet Legacy, Primordialism, and Patterns of Ideological Development since 1991. In: S. Akyildiz, \& R. Carlson (eds.). Social and Cultural Change in Central Asia: The Soviet Legacy (pp. 160-173). London-New York: Routledge.

Laruelle, M. (2008). Russian Eurasianism: An Ideology of Empire. Washington, DC: Woodrow Wilson Center Press.

Laruelle, M. (2015). In Search of Kazakhness: The Televisual Landscape and Screening of Nation in Kazakhstan. Demokratizatsiya: The Journal of Post-Soviet Democratization, 23(3), 321-340.

Lillis, J. (2011). Kazakhstan: Astana Harnesses Soft Power of Silver Screen. June 8. Retrieved from: https://eurasianet.org/kazakhstan-astana-harnesses-soft-power-of-silver-screen.

Lillis, J. (2015). Kazakhstan: Statehood Celebrations Remind Citizens Who's Boss. October 13. Retrieved from: https://eurasianet.org/s/kazakhstan-statehood-celebrations-remind -citizens-whos-boss.

Lillis, J. (2016). Kazakhstan: TV Epic Promises Game of Thrones-Style Thrills. January 25. Retrieved from: https://eurasianet.org/kazakhstan-tv-epic-promises-game-of-thronesstyle-thrills.

Marat, E. (2009). Nation Branding in Central Asia: A New Campaign to Present Ideas about the State and the Nation. Europe-Asia Studies, 61(7), 1123-1136. DOI: https:// doi.org/10.1080/09668130903068657.

Narymbetov, S. (2008). Mustafa Shokay. Kazakhfilm Studios.

Nazarbayev, N. (2010). V serdce Evrazii. Almaty: Zhibek Zholy.

Nijakowski, L. (2008). Polska polityka pamięci: esej socjologiczny. Warszawa: Wydawnictwa Akademickie i Profesjonalne.

Norris, S.M. (2012). Nomadic Nationhood: Cinema, Nationhood, and Remembrance in Post-Soviet Kazakhstan. Ab Imperio, 2, 378-402. DOI: https://doi.org/10.1353/ imp.2012.0072. 
Omelicheva, M. (2014). Eye on the International Image: Turkmenistan's Nation Branding. In: M. Omelicheva (ed.). Nationalism and Identity Construction in Central Asia: Dimensions, Dynamics, and Directions (pp. 91-110). London: Lexington Press.

Ponczek, E. (2015). Polityka historyczna w Polsce - od oglądu retrospektywnego do refleksji o następstwach przyszłościowych. In: K. Kącka, J. Piechowiak-Lamparska, \& A. Ratke-Majewska (eds.). Narracje pamięci: między polityka a historią (pp. 29-58). Toruń: Wydawnictwo Naukowe Uniwersytetu Mikołaja Kopernika.

Reputation Institute (2018). The World's Most Reputable Countries. Retrieved from: https:// www.reputationinstitute.com/sites/default/files/pdfs/2018-Country-RepTrak.pdf.

Satayev, A. (2012). Zhauzhürek myng bala. Kazakhfilm Studios.

Saunders, R.A. (2008). Buying into Brand Borat: Kazakhstan's Cautious Embrace of Its Unwanted “Son”. Slavic Review, 67(1), 63-80. DOI: https://doi.org/10.2307/27652767.

Stern, D.L. (2008). A Wandering Kazakh, Before Borat (Kazakhs Respond to Oscar Nomination of "Mongol"). The New York Times. February 24. Retrieved from: https:// www.nytimes.com/2008/02/24/weekinreview/24stern.html.

The First World "Kokpar" Championship (2017). Retrieved from: http://www.expo2017culture.kz/en/event/view?id=356.

Włodek, L. (2016). Osiadły Tadżyk vs. Koczowniczy Uzbek, osiadłość jako wartość w tadżyckiej ideologii narodowej. Studia Migracyjne - Przeglad Polonijny, 42(4), 57-75.

World Nomad Games 2018 (n.d.). Retrieved from: http://worldnomadgames.com/en/.

Yessenova, S. (2011). Nomad for Export, Not for Domestic Consumption: Kazakhstan's Arrested Endeavour to "Put the Country on the Map". Studies in Russian and Soviet Cinema, 5(2), 181-203. DOI: https://doi.org/10.1386/srsc.5.2.181_1. 